\title{
Managing of Collar Rot Disease in Groundnut (Arachis hypogaea L.) by few Chemicals
}

\author{
Suman Lora $^{1 *}$, Tahira Begum ${ }^{2}$ \\ ${ }^{1,2}$ Department of Botany, Samrat Prithviraj Chauhan Government College Ajmer, Rajasthan, India
}

Available online at: www.isroset.org

Received: 16/May/2019, Accepted: 19/Jun/2019, Online: 30/Jun/2019

\begin{abstract}
Groundnut (Arachis hypogaea L.) is an economically important edible oil seed crop of the world. The groundnut is affected by various pathogens like viruses, bacteria, fungi and nematodes. The collar rot disease of groundnut is caused by Aspergillus niger which is influenced by kharif crop production in some areas of Rajasthan. Different concentrations of few fungicides such as Mancozeb, Carbendazim, Antracol, Kemoxyl, Thiram,Captan and Hexaconazole are inhibited the mycelial growth of fungi. While Mancozeb and Carbendazim were found to effect the maximum mycelial growth of Aspergillus niger. In the present investigation antifungal activity of few chemicals was assayed in vitro by inhibition zone technique for Aspergillus niger.
\end{abstract}

Keywords- Groundnut, Aspergillus niger, managing chemicals (Mancozeb,Carbendazim, Antracol, Kemoxyle, Thiram,Captan and Hexaconazole).

\section{INTRODUCTION}

Groundnut (Arachis hypogaea L.) is commonly consumed as edible oil seed crop in India. Collar rot disease is one of the most common diseases of groundnut. Groundnut is believed to be a native of Brazil (South America) and it has been introduced to East Asia from South America [1]. In India Gujarat, Rajasthan, Tamil Nadu, Andhra Pradesh, Karnataka, Madhya Pradesh, Maharashtra, West Bengal, Uttar Pradesh and Orissa are largest groundnut growing states. Groundnut is one of the important food and feed crop, which also serve as the component of crop rotation in the many countries $[2,3]$.

Chemical control using fungicides is a part of integrated plant disease management to control Aspergillus niger. A. niger is a saprophyte, filamentous fungus having smooth walled, hyaline conidiophores. Conidia are globose to sub globose $(1.38 \mu \mathrm{m}-4 \mu \mathrm{m}$ diameter), dark brown to black and rough walled [4]. In Rajasthan due to warm climates grains are easily infected with Aspergillus niger. Annual world yield losses by the disease are more than $10 \%$ and fungus is prevalent in soils with the low moisture and approximately $30^{\circ} \mathrm{C}$ temperature $[5,6,7]$. Collar rot is an important disease of groundnut growing field areas of the Rajasthan state. The maximum disease incidence (25-50\%) was reported in Rajasthan [7,8 ]. Aspergillus niger was the most toxic fungus and causing yellowing of the leaves, blighting effect on the shoot part and at last finally leading to death of crown portion of the plants [9]. The objective of this study was "In vitro conditions to evaluate effectiveness of few fungicides against Aspergillus niger and collar rot disease of groundnut."

\section{MATERIAL AND METHODS}

Diseased plant samples were collected from Ajmer and Nagaur districts of Rajasthan. In vitro study of mycotoxicity of different fungicides against Aspergillus niger was done on Mancozeb, Carbendazim, Antracol, Kemoxyle, Thiram, Captan and Hexaconazole were used.

\subsection{In vitro fungicides testing for analysis of mycelial growth-}

Potato Dextrose Agar plates containing fungicides solutions at desired concentrations (50ppm, 100ppm, 200ppm, $500 \mathrm{ppm}$ and $1000 \mathrm{ppm}$ ) were used. Fungicides were mixed thoroughly in PDA just before pouring in sterilized petri plates and allowed to solidify. All the plates were kept in incubator for incubation at $25^{\circ} \mathrm{C}$ for 7 days and allowed to spread the infection against the fungicides.

\subsection{Germination of groundnut to check pathogenicity test of Aspergillus niger- \\ Plastic glasses having autoclaved soil were added groundnut seeds. The plastic glasses were irrigated with water as needed and allowed to grow as matured plant for 15 days. After maturation of plants cultured Aspergillus niger (in peptone water) was injected in soil by using syringe.}


Treatment of spray and drenching-

\begin{tabular}{|l|l|l|l|}
\hline S.N. & Methods of application & Dosage & Remarks \\
\hline 1 & Foliar Spraying & $0.1 \%$ & $\begin{array}{l}\text { Start after 25 days at 7 days } \\
\text { intervals }\end{array}$ \\
\hline 2 & Soil Drenching & $0.1 \%$ & $\begin{array}{l}\text { Start after 25 days at 7 days } \\
\text { intervals }\end{array}$ \\
\hline
\end{tabular}

\section{RESULTS AND DISCUSSION}

3.1 Effect of different Fungicides on growth of Aspergillus niger in vitro -

The effect of seven fungicides (Mancozeb, Carbendazim, Antracol,Kemoxyle,Thiram,Captan and Hexaconazole )were tested in vitro under laboratory conditions for the inhibition of mycelial growth of Aspergillus niger. In the solid medium method fungus was inoculated and observations was took after 25 days. Under in vitro conditions the tested fungicides inhibited the mycelial growth. Mancozeb and Carbendazim at $500 \mathrm{ppm}$ and 1000 ppm was inhibited 100\% mycelial growth (Table-1 and fig.).In Vitro conditions the Mancozeb and Carbendazim completely inhibited the fungus growth at higher concentration(1000 ppm) [10]. Mancozeb and Carbendazim are completely inhibited the mycelium growth of Aspergillus niger at $500 \mathrm{ppm}$ and $1000 \mathrm{ppm}[11]$. Five fungicides Antracol,Kemoxyle,Thiram, Captan and Hexaconazole at low concentrations were less effective. These fungicides possesses residual curative and systematic qualities against the infection of Aspergillus niger.

\subsection{Protection of groundnut plant by spraying and drenching of few fungicides-}

It was found that collar rot disease was also controlled by foliar spray and soil drenching methods. In comparison to foliar sprays, soil drenching method gave much better results. In spraying and drenching methods, same concentrations of fungicides were used. Different fungicides may differ in their intrinsic capacity to stick to foliage. Thiram had a much batter tenacity than other fungicides so during experiment it gave positive results. Distribution of spreading of spray droplets on the plant surface may also influence. Thiram and Captan fungicides are comparatively safer fungicides. Thiram and Captan both fungicides protect the plants from collar rot disease (Table-2).Carbendazim is a widely used broad spectrum fungicide.

Table- 1 Percentage inhabitation of mycelial growth of Aspergillus niger exposed to seven fungicides ( concentrations in ppm)-

\begin{tabular}{|l|l|l|l|l|l|l|}
\hline Fungicides & $50 \mathrm{ppm}$ & $100 \mathrm{ppm}$ & $200 \mathrm{ppm}$ & $500 \mathrm{ppm}$ & $1000 \mathrm{ppm}$ & Mean \\
\hline Mancozeb & 63.34 & 80.65 & 89.65 & 100 & 100 & 86.73 \\
\hline Carbendazim & 62.34 & 78.85 & 85.56 & 100 & 100 & 85.35 \\
\hline Antracol & 21.78 & 24.56 & 43.56 & 51.67 & 64.45 & 41.20 \\
\hline Kemoxyle & 20.54 & 22.98 & 42.34 & 48.67 & 62.23 & 39.35 \\
\hline Thiram & 25.10 & 42.30 & 52.45 & 58.42 & 71.76 & 50.06 \\
\hline Captan & 0.40 & 52.23 & 62.42 & 71.32 & 79.10 & 53.09 \\
\hline Hexaconazole & 0.40 & 0.40 & 0.40 & 0.45 & 0.50 & 0.43 \\
\hline Control & 0.0 & 0.0 & 0.0 & 0.0 & 0.0 & 0.0 \\
\hline
\end{tabular}




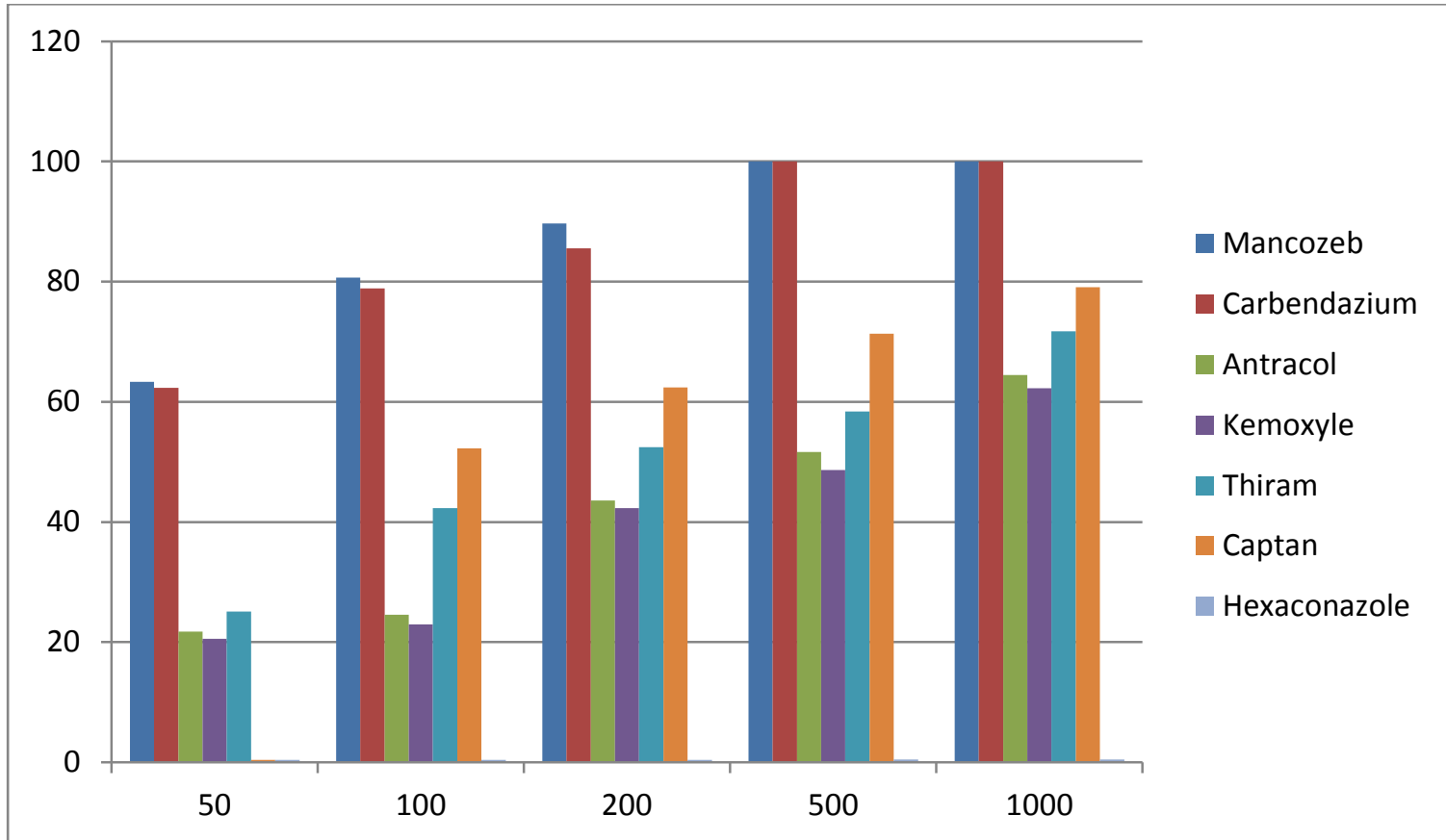

Fig.1-Comparison of few fungicides on percentage inhibition of mycelial growth of Aspergillus niger

$\mathrm{x}$-axis is representing fungicides concentration in ppm

$\mathrm{Y}$-axis is representing Aspergillus niger growth inhibition in \%

Table-2 Effect of fungicides ( $0.1 \%$ concentrations ) by foliar spraying and soil drenching on collar rot disease of groundnut-

\begin{tabular}{|c|c|c|c|c|c|c|c|c|}
\hline \multirow[t]{2}{*}{ Fungicides } & \multicolumn{2}{|c|}{7 days } & \multicolumn{2}{|c|}{14 days } & \multicolumn{2}{|c|}{ 21days } & \multicolumn{2}{|c|}{28 days } \\
\hline & FS & SD & FS & SD & $\mathrm{FS}$ & SD & FS & SD \\
\hline Mancozeb & - & - & - & + & + & + & + & + \\
\hline Carbendazim & - & - & - & + & + & + & + & + \\
\hline Antracol & - & - & - & + & + & + & + & + \\
\hline Kemoxyle & - & - & - & - & - & - & + & + \\
\hline Thiram & + & + & + & + & + & + & + & + \\
\hline Captan & - & - & + & + & + & + & + & + \\
\hline Hexaconazole & - & - & - & - & - & - & + & + \\
\hline Control & - & - & - & - & - & - & - & - \\
\hline
\end{tabular}

NOTE-: Here( +) Eeffect of fungicides

(-) Less effect of fungicides

F S - Foliar Spraying on collar rot disease

S D- Soil Drenching on collar rot disease 


\section{CONCLUSION}

In Vitro two fungicides Mancozeb and Carbendazim were more effective in inhibiting the mycelial growth of Aspergillus niger. Mostly all the fungicides tested in this study either in vitro or foliar spray, soil drenching method inhibited the mycelial growth of Aspergillus niger. But only Hexaconazole was not effective. It was also found that combined fungicides Mancozeb and Carbendazim (250ppm conc.) proved to be the most effective in inhibiting the growth of Aspergillus niger[7]. It was concluded that the use of these fungicides should be control the collar rot disease in groundnut (Arachis hypogaea). Foliar spray and soil drenching methods are not harmful for plants as well as physical properties of soil.

\section{ACKNOWLEDGMENT}

The authors are grateful to Department of Botany, Samrat Prithviraj Chauhan Govenrment College Ajmer, Rajasthan for providing laboratory facilities. We are also thankful to Dr. R. D. Meena for confirming the identify of Aspergillus niger.

\section{REFERENCES}

[1]. Weiss, A., Van Crowder, L. and M.Bernardi, M. Communicating agrometerological information to farming communities. Agricultural Forest Meterology 103:185-196, 2000.

[2]. Pande N, Saxena J,Pandey H. Natural occurrence of mycotoxins in some cereals.Mycoses.33:126-128, 2003.

[3]. Upadhyaya HD, Reddy LJ, Gowda CLL,Singh S. Identification of diverse groundnut germplasm :Sources of early maturity in a core collection. Field Cro.Res.97:261-271, 2006.

[4]. Kumari M, Singh M. Bio-intensive management of collar rot disease of groundnut (Arachis hypogaea L.)caused by Aspergillus niger. International Journal of Chemical Studies.2017;5(4):80-82.

[5]. Pande S, Rao JN. Changing scenario of groundnut diseases in Andhra Pradesh, Karnataka and Tamil Nadu states of India. International Arachis Newsletter. 2000; 20:42-44.

[6]. 6.Kishore GK, Pande S, Harish S. Evaluation of essential oils and their components for broad-spectrum antifungal activity and control of late leaf spot and crown rot diseases in peanut. Pl. Dis. 2007; 91:375-379.

[7]. Kumari M, Singh M. shailesh godika, Sangeeta Choudhary and Jitendra Sharma. Effect of different fungicides, plant extracts on incidence and varietal screening against collar rot of groundnut (Arachis hypogea L.) Caused by Aspergillus niger van tiegham. 2016; 11(4):2835-2839.

[8]. Bakhetia DRC.Control of white grub (Holotrichia consanguinea) and collar rot (Aspergillus niger) of groundnut sown in different dates in Punjab.India J.Agric.Sci.1983;53(9):846-850.

[9]. Suzui T and Makino T Occurrence of Aspergillus crown rot of peanut caused by Aspergillus niger van Tieghum. Annauls of the Phytopathological society of Japan $46: 46-48,1980$.
[10]. Singh PC, Singh D. In vitro evaluation of fungicides against Alternaria alternata. Ann. Pl. Protec. Sci. 2006; 14:500-502.

[11]. Sharma Divya P. Chaudhary Lata Nain, Saxena AK, Shashi B. Singh Isolation and characterization of Bifenthrin degrading fungal isolates from acclimatized soil. Ann. Pl. Protec. Sci. 2012; 20:172-176

\section{Author's profile}

Ms. Suman Lora is a research scholar, Department of Botany, Samrat Prithviraj Chauhan Government College Ajmer, Rajasthan, India . She has completed M.Sc. Degree in Botany from M.D.S.University Ajmer, Rajasthan, India.

Dr. Tahira Begum is currently working as Associate Proffessor, Department of Botany, Samrat Prithviraj Chauhan Government College Ajmer, Rajasthan, India. She has awarded with a Ph.D degree in Botany from Maharshi Dayanand Saraswati University, Ajmer, Rajasthan, India 